\title{
THE PLACE OF ANIMALS IN CHRISTIAN AMERICA
}

\author{
GERALD E. JONES
}

Berkeley Institute of Religion

Since Henry Bergh organized the first American Society for the Prevention of Cruelty to Animals in 1866, there have been nationwide efforts to curb cruelty to animals.[1] The "Humane Society" and the "Band of Mercy" have joined this crusade, along with numerous other groups aimed toward some specific act of cruelty.[2] Groups which indirectly advocate kindness to animal life are the Vegetarians and Anti-Vivisectionists. As a result of public pressure, laws have been passed in nearly every state making it a misdemeanor to treat animals cruelly. In 1960, slaughter-houses were required by law to treat animals in a more humane manner just previous to killing them for public consumption. [3]

How does the Christian in America react to all of this? In the following pages, I hope to indicate what some Christian organizations have done. An arbitrary categorization will be made to facilitate discussion. Christian efforts will be discussed under the headings of "Utilitarianism" (dogmatic and humane), "Relatives," "Civil Rights," and "Empathy."

\section{Utilitarianism}

one type of utilitarianism involves stressing the humane treatment of animals as a means to an end. This type is exemplified by the Band of Mercy. The Band of Mercy was organized in 1882, and George Angell helped to get the Protestant and Catholic Sunday schools or youth groups to organize as local Bands of Mercy or Junior Humane Leagues. A pledge to be kind and just to all living creatures was to be the cardinal ideal. Within forty years, there were 4,000,000 members registered. This type of organization plays on many sympathies. The care of personal pets is stressed. Stories of animals' devotion to human masters are related. Pictures of Jesus carrying a lamb also help to impress a Christian charity towards animal life. [4]

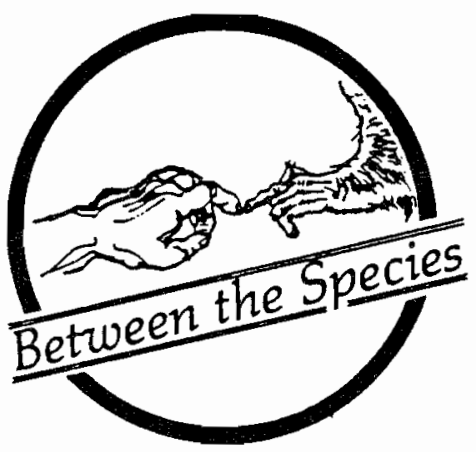

Adults encourage this general humane education as being excellent training for the young. The underlying principle here is that by leaming kindness to animals, we may transfer this kindness to our fellow humans. A classic expression of this principle is found in Martin Luther's commentary on Deuteronomy $22: 6$, where he says: by the kind treatment of animals they are to learn gentleness and kindness."[5] However, there actually is a great problem in this movement. Like the Santa Claus concept, children are taught or, at least, allowed to give their affection to the animals, but the adults know that this is only for a possible fringe benefit. Before adulthood children become aware of the myth, and their feelings towards animals seldom remain the same.

In the above situation, we have people using animals as a teaching device. But, again, as with some health-oriented groups to be discussed later, there is no actual, ethical concern for the animal or for the humananimal relationship. The moral of the Genesis creation is practiced with people ruling over the beasts of the field, which are to be used for human benefit and pleasure.[6]

A dogmatic approach to utilitarianism is represented in the Seventh-Day Adventist. movement. The Seventh-Day Adventists have stressed the vegetarian diet for over a century. Their official basis for their diet is similar to the vegetarian groups in being basically a matter of health. In fact, they disclain any Mosaic taboos in regard to their

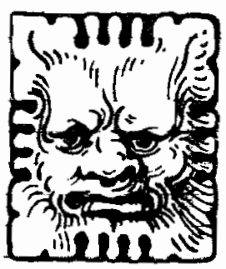




\section{THE ARTIST AND THE LOBSTER}

Japanese doll, dainty in traditional dress, bearing with pride the gastronamic work of art; cadmium red, bold and hard as Spanish ceramic. harshly outlined against sprays of parsley viridian. The artist says, "It's a painting; I'll take the shell home to draw; see the angle of the feelers." Others, salivating, dip plump white morsels and take them between their teeth, buttery sauce drooling down their chins. I look and look away, my mind on the victim of their ecstasy; once a living, feeling thing creeping along crusty sea bottoms, outer skeleton a mottled-mauve green, Nature's own camouflage

not concealed from the lobster trap; snared and captured, pincers pegged and bound, imprisoned in icy water tanks until the gentle Japanese maiden grasps its skeletal sides, flings it into the iron pot and doesn't watch as it churns and struggles in boiling death, feelers twisting in agony into shapes the artist will draw.

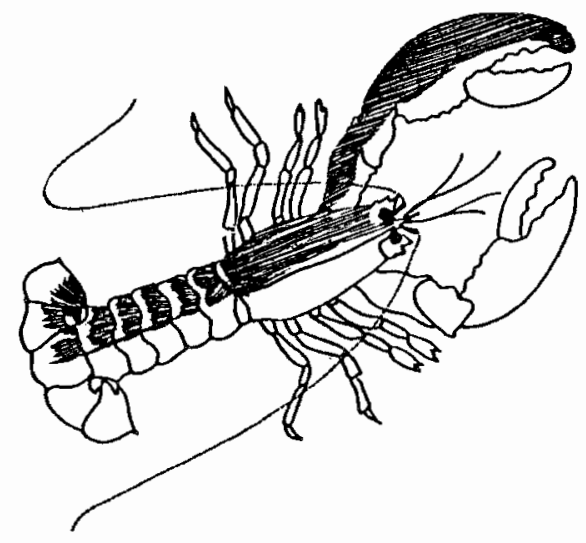

Mary Sternberg health laws. The doctor has replaced the preacher in advocating the vegetarian life for the members of this church.[7] The result is an ego-centric position, with people's only concern with nature being a clinical one.

The Roman Catholic position is explained in the Catholic Encyclopedia:

Catholic doctrine, though it does not concede rights to the brute creation, denounces cruelty to animals. . God's purpose in reconmending kind treatment of the brute creation is to dispose men to pity and tenderness for one another. [8]

Though this sounds very similar to the humane Bands of Mercy, the key here is the fact that animals are not conceded to have rights themselves.

Though Thomas Aquinas may be read as advocating kindness to animals in order to teach us to be kind to people, there is a more logical ordering for a Catholic's concern. Since our first duty is to $\mathrm{God}$ and then to our fellow humans, we should . start our humane endeavors at the top of the scale. If we have an abundance of charity to spare, then we may be kind to the animal world. [9] Though the Catholic may be accountable before God for his/her treatment of animals, he/she should be quite aware of the danger lurking in the "empathetic fallacy." The lack of a rational soul "renders impossible any relation of justice or charity to the animal world."[10] Indeed, loving animals as ourselves is considered a "blasphemy against grace."[11]

As a result of scholastic studies concerning the rights of animals, there is another aspect of Catholic thought which qualifies the above conclusion. According to Catholic doctrine, when wanton pain is inflicted on an animal, it is a sin against the divine order. [12]

on the other hand, we have Jonathan Edwards. A. C. MoGiffert explains Edwards' view that treatment of animals is legislated by the divine order of things, according to which, it is a sin to show too much love towards animals, because they are on a lower scale of being. Benevolence should be directed toward the Highest Being, God.[13] 


\section{Relatives}

John Wesley was converted to vegetarianism, but he actually lived its precepts only for a couple of two-year periods. He recognized a definite health value to vegetarianism but also spoke of the millenial reign wherein there would be no killing or pain for animals. [14] In his works, we find that even though there was a "golden chain" of being from God on down to matter, [15] humans and animals are "the offspring of our conmon father, the creature of the same God of Love!"[16] This suggests that men should treat animals kindly as some sort of kindredbeing on our Father's earth. Indeed, during the millenial paradise, all creatures will live in peace with one another, as Isaiah 11:6-9 foretells. Perhaps Bishop Joseph Butler's concept of an animal resurrection is a part of this attitude. [17]

Perhaps the first Christian organization advocating kindness to animals was the result of the Reverend William Cowherd's efforts in England. William Metcalfe led a group fram England to Philadelphia in 1817, establishing the Bible Christian Church in America. One of the main tenets of this sect was a vegetarian diet, based on scriptural references, such as Isaiah 66:3, Romans 14:21, Genesis 9:4, and the Sixth Commandment. They gained from Cowherd the ideas that we have a moral obligation to be kind to animals and that all life is sacred. Since they are a creation of God, animals should be respected. Though the Bible Christian Church no longer exists, the Reverend Metcalfe left a legacy in the American Vegetarian society, which he helped to found. This society still embraces many Christian concepts, even though it is now basically a secular organization. [18]

The most vocal representation today of our kinship to animals is found in naturalistic humanists who feel that we are related on the evolutionary scale as a direct descendant of the beasts. This view was expressed in the classical era by Celsus and was subscribed to during the Enlightenment by such figures as Rorario, Boaystuau, Montaigne, Iamartine, and Diderot. Evolutionists in humane societies and vegetarian groups often quote from these pioneers. [19]

outside of Christianity, the "ahimsa" doctrine of the Jain--and, to a certain extent, of the Buddhist and Hindu--is involved in the belief in reincarnation. Here, to a degree at least, the respect for animal life is respect for reincarnated souls.[20] This view has found very little support in Christian America, however.

\section{Civil Rights}

Among those who advocate zoophily (love of animals) are those who do not fit, or at least would not necessarily claim, any of the above descriptions. They just believe that since animals are living creatures, they have rights of their own. Just because they exist, animals deserve to be treated with kindness and respect. The comic strip "Little Orphan Annie" has advanced a view of this type. [21] Though an attempt has been made by the cartoonist to show human characteristics in animals (or is it the other way around?), this is not given as the reason for treating them with respect. Here, the reason that we should be kind to animals is that they have "natural" rights. Also to be included here are those who believe that animals have rights because they are creatures in God's creation.

A pantheistic view of the universe often leads to a desire to be equally just to all members of the universe. This is part of an effort towards a type of universal unity.

Of the above views, "Iittle Orphan Annie" may be dismissed, because the thought structure behind the principle advocated there is as undeveloped as Annie's eyeballs.

\section{Empathy}

There are people who give no reason for their kindness to animals beyond a feeling of empathy with their suffering. Jeremy Bentham pleads in a fashion typical of this attitude: "The question is not, can they reason? nor, can they talk? but, can they suffer?"[24]

Albert Schweitzer"s "reverence for life" is often wrongly considered a Christian ethic. Schweitzer does not call upon the Christian gospel to either ground or develop his ethic. Furthermore, he acknowledges that primitive Christianity held a negative attitude to the world and that it was not until the Renaissance that Jesus" principle of love was accepted as a practical guide in a more life-affirming world.[23] Nonetheless, there are two reasons why Schweitzer's ethic should 
be considered in our discussion: he is very widely known in America, and he has made scholarly efforts within the Christian context. He does express an existential empathy in one of the few developed expressions of zoophily.

W. D. Geoghegan feels that Schweitzer has been neglected and should be recognized more as one of the "foremost exponents of a spirit which is profoundly, sensitively, and authentically Christian."[24] Though Geoghagen points out some admirable qualities of a "sense of thought and existence" and a "sense of synthesis," he fails to show schweitzer as being a Christian. Nor does he show that schweitzer's ethic is Christian-based, or even that Schweitzer's ethic may be used in a Christian context. [25] Indeed, it seems that Schweitzer eliminates this possibility when he describes the world as a

wonderfully creative force, and at the same time a senselessly destructive force. We face her absolutely perplexed. What is full of meaning within the meaningless, the meaningless within what is full of meaning; that is the essential nature of the universe.[26]

This does not sound like a Christian view of the world under God! Nor do the following statements help in our search for Christianity within Schweitzer's ethics. Compare a Christian's hope with

I can do nothing but hold to the fact that the will-to-live in me manifests itself as will-to-live which desires to become one witn other wills-to-live. That is for us the light that abides in the darkness. [27]

Furthermore, he can find no guide:

In Ethical conflicts man can arrive only at subjective decision. ... The good conscience is an invention of the devil.[28]

In the above statements, we find that Schweitzer's ethic has no place for either Christian law or spirit. In his treatment of animals, he admits of no standard to guide him. Worse, for Schweitzer, is the fact that though he must subjectively decide what to do each time he is confronted with another liv- ing being, neither his conscience, the law, nor the spirit will be able to help him. He is continually brought to a sense of guilt, with no hope of redemption.[29] The only thing to do is submit to the surrounding world.[30] The only way to step out of this "incomprehensible horror of existence" for a moment is to bring help to some animal, in order to compensate in some degree for humanimposed misery.[31] Instead of speaking of a savior in Christ, we become the savior of ourselves and of the animal world, as well.

Though the above may sound critical, it is not intended to detract from the validity of Schweitzer's argument within his context. The point of the above analysis is that Schweitzer's is a "Christian alternative" which ends up not being very Christian at all, though it may be an excellent alternative. Schweitzer makes a substantive point in claiming that other systens are incormlete if they do not at least take into account the relationship of humans to the animal world.[32] Being part of God's creation makes animals eligible for ethical concern.

Perhaps a word should be said concerning modern philosophical endeavors. Modern philosophical thought would be quite embarrassed if caught discussing a subject like zoophily. Many modern philosophers are unwilling to discuss even substantive ethical problems concerning intra-human relations. When Ayer and stevenson speak of ethics, they conclude that our only ethical standard is our own emotional attitude at the moment and, therefore, that acts are "good" if they express the way we feel and affirm our attitudes. [33] Mill's "greatest good for the greatest number" was strictly a hedonism for humans. But, even if Mill had included animals, the theory has been demonstrated to be impractical.[34] No help for animals here! Perhaps, for all practical purposes, Descartes' dismissal of animals as machines is still in vogue.

\section{Conclusions}

Without doubt, the utilitarian view is the most prevalent view in America today. This includes both those who have and those who have not thought much about zoophily. Pragmatically, utilitarianism seems to be the most productive ethical system to have come along, and for the general public, nothing is 
as attractive as success.

Underlying vegetarianism, there are elements of naturalistic humanism wherein humans' physical and mental well-being are accomplished by following the laws of health which nature intended for people. [35] Sometimes inherent human goodness is expected to keep us above the animal plane of killing other, living creatures. It is claimed that in abstaining from flesh, our minds are more at peace with the world around us, though still quite superior to that world. The Christian vegetarians usualiy hold that there are biblical accounts of great teachers struggling to teach this truth to humankind. [35]

A sense of security comes with believing that there is a God and that He/She sanctions our using animals for our purposes. St. Francis of Assisi embarrasses this sense of security by showing that humans can have an intense love of animals. However, St. Francis' position is not satisfying for those who wish to feel more united with the world about them, although those who advocate being humane only for the dubious educational effects it may have on children are in an even more inadequate position. We blaspheme any true humanitarianism to animals by our inconsistency. How long can we pretend to have warm hearts for animals while coldly acting from selfishness?

The position which focuses on our kinship with animals suggests a path to consistency. If we assume that humans and other animals developed from a cormon ancestor, then as members of one, big, unhappy family, we are in this world together. We can approach this situation with a feeling of respect for our cousins. Indeed, as the most advanced branch of the family, it is claimed that we ought to set the pace for gentility. Unfortunately, this is not what we have been doing! We find less kindness in human history than in the animal kingdom. We do not kill for necessity but for "sport," greed, lust, or power. The epithet of "brutality" seems to belong most to "civilized" humanity. We insult the beasts when we suggest that they are as beastly as we are.

Animals' rights may be those imagined by humans, or they may be divinely imposed. The first possibility is untenable; the second is debatable. The first possibility requires a curious mixture of empiricism, rationalism, and intuition to explain it coherently. The second possibility, on the other hand, opens the Pandora's box of revelation: Has there been a revelation concerning our relation to animals? Does it come from God? Who is accountable for what? I would not say that these probiens are irresolvable, but that they exist needs to be recognized.

The empathy position is a highly individualized one. Even in Schweitzer's recognition of a universal tension in the will-tolive, there is no satisfactory explanation of the universality of reverence for all life. Pantheism would seem to be the direction in which one would have to seek such explanation. That does not sit well with Christians.

So, as in attempting to deal with any contemporary, ethical problem, we are faced with a pluralistic society with a multitude of ethical systems, some rationally developed, some not. In our discussion of them, we find ourselves using such tools as intuition, empiricism, pragmatism, and reason. We find flaws in others' systems but seldom realize that we are not consistent in our evaluations. Ultimately, all of our efforts are still unconvincing. Humans exist in a world of perplexity, and in the long run, we opt for what we will and plug along somewhere between the edges of bliss and dread. If there has been a communion between human and Ultimate Reality or a God that we recognize, then there is additional help. May you and your dog have peace.

Notes

1. Donald Peattie, "He Invented a New Kind of Goodness," Readers Digest 39 (1941), pp. 95-8.

2. William J. Shultz, The Humane Movement in the United State 1910-1922 (New York: Columbia University Press, 1924), pp. 9-319.

3. "Humane Killing," Business Week 1539 (Fèbruary 28, 1959), p. 39.

4. Shultz, op. cit.., p. 130.

5. Jaroslav Pelikan, ed., Luther's Works, IX (St. Louis: Concordian Publishing House, 1960), p. 220. 


\section{Genesis 1:29.}

7. Seventh-Day Adventist Leaders, Teachers, and Editors, Questions on Doctrine (Washington, D.C.: Review and Herald Publishing AssoC., 1957), Question 47, pp. 6224.

8. James J. Fox, "Cruelty to Animals," in The Catholic Encyclopedia (New York: The Universal knowledge Foundation, Inc., 1908), p. 542 .

\section{Ibid.}

10. "Empathetic Fallacy," (unsigned editorial) America 101 (August 1, 1959), p. 567.

11. Ibid.

12. Fox, op. cit., p. 543.

13. A. C. McGiffert, Protestant Thought Before Kant (New York: Harper and Brothers, 1962), pp. 182-3.

14. John Wesley, The Works of John Wesley, volume $V$ (London: Wesleyan Conference Office, 1872), p. 294.

15. Ibid., pp. 211-3.

16. Ibid., p. 294.

17. Joseph Butler, The Analogy of Religion, Natural and Revealed, to the Constitution and Course of Nature (Cincinnati: $\mathrm{Me}^{-}$ thodist Episcopal Church, 1860).

18. Geoffrey L. Rudd, Why Kill for Food? (Wilmslow, Cheshire: The Vegetarian society, 1956), p. 4, and Gerald Carson, Cornflake Crusade (New York: Rinehart and Company, 1957), pp. 16-8.

19. George Boas, The Happy Beast (Baltimore: The Johns Hopkins University Press, 1933), pp. 10-40.

20. P. D. Mehta, Early Indian Religious Thought (London: Luzac and Co., Ltd., 1956), p. 154 .

21. Harold Gray, "Little Orphan Annie," Salt Lake Tribune canic section (June 16, 1963).

22. David Burgardt, Bentham and the
Ethics of Today (Princeton: Princeton University Press, 1952), p. 308.

23. Albert Schweitzer, "The Problem of Ethics for Twentieth-Century Man,." Saturday Review 36 (June 13, 1953), p. 11.

24. William D. Geoghegan, "Albert Schweitzer's Covenant with Life," Religion in Iife XXX (1961), p. 256.

25. Ibid., pp. 256-67.

26. Albert Schweitzer, Civilization and Ethics, third edition, (London: Adam \& Charles Black, 1949), p. 205.

27. Ibid., p. 246.

28. Ibid.., pp. 251-2.

29. Charles R. Joy, ed., The Animal World of Albert Schweitzer (Boston: The Beacon Press, 1950), p. 190.

30. Ibid.

31. Ibid., p. 192.

32. Schweitzer, "The Problem of Ethics for Twentieth-Century Man," pp. 9-11, 46-8.

33. C. I. Stevenson, "The Emotive Meaning of Ethical Terms," and A. J. Ayer, "The Erotive Theory of Ethics," in Readings in Ethical Theory, eds. Wilfrid Sellars and John Hospers, (New York: Appleton-Century-Crofts, Inc., 1952), pp. 415-51.

34. G. E. Moore, "Utilitarianism," in Readings in Ethical Theory.

35. Rudd, op. cit.

36. Ibid.. pp. 78-90. 